\title{
The benthic decapod fauna in the channels and fjords along the South Patagonian Icefield, Southern Chile*
}

\author{
ERIKA MUTSCHKE and MATTHIAS GORNY \\ Instituto de la Patagonia, Universidad de Magallanes, Casilla 133-D, Punta Arenas, Chile.
}

\begin{abstract}
SUMMARY: The species composition and distribution of decapod crustaceans opposite the South Patagonian Icefield (SPI) was analyzed by means of 33 Agassiz trawl hauls, taken during August 1995 and October-November 1996 from board RV "Vidal Gormaz". A total of 13 benthic decapod species were found, and the material yielded a total of 248 individuals. In addition, the pelagic shrimp Pasiphaea acutifrons appeared in just one haul. The number of species declined from the Pacific towards the inner fjords. Brachyura was the most frequent group within all areas, whereas caridean shrimps were frequent only in the channels and anomuran crabs in the fjords. Altogether the decapod species covered the whole depth range of sampling between 45 and $1218 \mathrm{~m}$. Species number of decapods in the waters along the SPI was low, compared to a total number of 46 species, which are known from the total area between Chiloé island and the Straits of Magellan. The low species number may be related to the impact of the glaciers in southern Patagonia.
\end{abstract}

Key words: Southern Patagonian Icefield, benthic decapods, distribution.

RESUMEN: Fauna bentónica de decápodos en fiordos y Canales del Campo Patagónico de Hielo Sur, SuR de Chile. - La composición de especies y distribución de los crustáceos decápodos frente al Campo Patagónico de Hielo Sur (CPHS) fue analizada a partir de 33 muestras obtenidas desde el B/O "Vidal Gormaz" mediante una red de arrastre Agassiz, durante los meses de agosto de 1995 y octubre-noviembre de 1996. Se encontraron 13 especies de decápodos bentónicos, el material proporcionó un total de 248 especímenes. La muestra incluyó al camarón pelágico Pasiphaea acutifrons en un solo lance. El número de especies declinó desde el Pacífico a los canales y fiordos interiores. Brachyura estuvieron presentes en las tres áreas, Caridea fueron frecuentes sólo en los canales y Anomura en los fiordos. Los decápodos cubrieron todo el rango de profundidad entre los 45 y los $1218 \mathrm{~m}$. La diversidad de los decápodos en las aguas a lo largo del CPHS fue baja en comparación con el total de 46 especies conocidas para el área comprendida entre la isla de Chiloé y el Estrecho de Magallanes. Se discute que el bajo número de especies puede estar relacionado con el impacto de los glaciares en la Patagonia austral.

Palabras clave: Campo Patagónico de Hielo Sur, decápodos bentónicos, distribución.

\section{INTRODUCTION}

The Chilean coastline south of Chiloé Island $\left(42^{\circ} 30^{\prime} S\right)$ is characterized by a network of numerous channels and fjords, with large parts still covered by glaciers. The South Patagonian Icefield (SPI) is the biggest glacier field in the

\footnotetext{
*Accepted June 11, 1999
}

southern hemisphere, covering an area of approximately $13,000 \mathrm{~km}^{2}$ between $48^{\circ} 10^{\prime} \mathrm{S}$ and $51^{\circ} 30^{\prime} \mathrm{S}$ along the $73^{\circ} 30^{\prime} \mathrm{W}$ meridian (Aniya and Skvarca, 1992). The dense fjord and channel net opposite the SPI is connected with the Pacific Ocean (Fig. 1), and repeated glaciation since late Miocene has structured the landscape and the fjords (Warren and Sudgen, 1993; Aniya and Skvarca, 1992). 


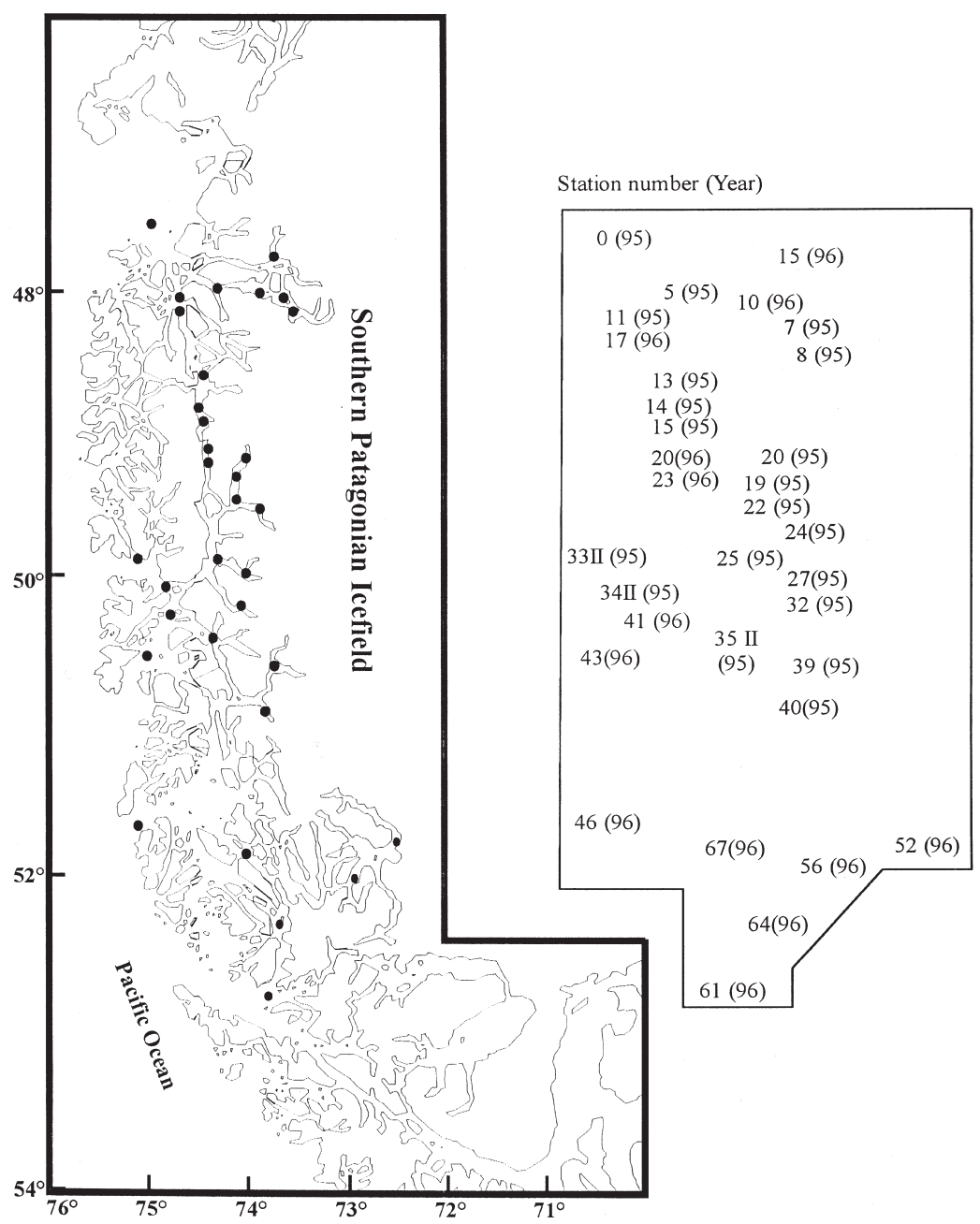

FIG. 1. - Map of the sampling stations in front of the South Patagonian Icefield

Knowledge of the decapod fauna in this area was rather limited (Retamal, 1973, 1974), and species composition within most of the fjords and channels was nearly unknown. Some occasional collections in the fjords were made during the expeditions of the "Challenger" (1873-1876), but all detailed information on the decapods in the south-western part of the Pacific Ocean referred either to the waters north or south of the SPI. The Canadian expedition of the C.S.S. "Hudson" in 1970 covered the area of the SPI, but work was restricted to physical oceanography, exclusively (Cáceres, 1997, pers. comm.).

The aim of this study was to describe the species composition, occurrence and distribution of decapod crustaceans in a particular part of the southern Chilean channels and fjords. The results were compared with other areas north and south of the SPI, which are not influenced by recent glaciation, and with similar environments in the northern hemisphere.

\section{MATERIAL AND METHODS}

The decapod material was obtained during two expeditions of RV "VIDAL GORMAZ" in the channels and fjords opposite the SPI (August 1995, October/November, 1996). The stations were located between $45^{\circ} 03^{\prime} \mathrm{S}, 73^{\circ} 36^{\prime} \mathrm{W}$ and $52^{\circ} 45^{\prime} \mathrm{S}$, $73^{\circ} 48^{\prime} \mathrm{W}$ (Fig. 1).

In the study area the sediments in most of the fjords were found to be dominated by clay and silt. At some places, mainly in the southern channels, the bottom is hard substrate or is covered by stones and boulders of varying size (Ríos and Guzmán, 1982). According to Pinochet and Salinas (1995) salinity and temperature generally decrease towards the glaciers, and increase from the surface to the bottom, due to a permanent supply of melt water from the glaciers and continental runoff (Heusser, 1984). Salinity varied between 14 PSU (surface) and 33 PSU (bottom). Below $200 \mathrm{~m}$ depth the minimum 
salinity was 32.0 PSU at all stations (Pinochet and Salinas op. cit.). Water temperature of some fjords varied between $0^{\circ} \mathrm{C}$ at the surface and $11^{\circ} \mathrm{C}$ at the bottom.

Decapods were collected from a series of 33 successful Agassiz trawl catches. A total of 15 stations were located inside the fjords, with some of them next to the edge of the glaciers, 11 stations were situated in the channels between the islands and the coastline, and 7 stations were located on the Pacific side of the outerlying islands close to the open sea. Details of all stations are presented in Table 1.

The sampling gear was a modified Agassiz trawl (cf. Arntz et al., 1999). Most of the AGT hauls were taken between 100 and $400 \mathrm{~m}$ depth.

All decapods were picked from each catch, preserved in a $5 \%$ formaldehyde-sea water solution, buffered with borax. Species identification based on the descriptions of Holthuis (1952) and Boschi et al. (1992).

\section{RESULTS}

Decapod crustaceans were present at 20 stations and distributed in the entire area of the study, but species composition and the frequency of occurrence varied among the channels and fjords. Altogether 13 benthic species were found, comprising the infraorders Caridea with 3, Anomura with 5, Brachyura with 4 and Palinura with one species. In addition, Liopetrolisthes patagonicus (Anomura) was obtained at one station by scuba diving, and the pelagic caridean shrimp Pasiphaea acutifrons Bate, 1888 (Pasiphaeidae) occurred in 1 haul. The most frequent infraorder were brachyuran crabs, followed by Anomura and Caridea. The only representative of the Palinura, Stereomastis suhmi, was caught occasionally. The detailed species composition is presented in Table 1.

The number of species declined from the Pacific towards those stations located in the inner fjords. Brachyura were the most frequent group next to the Pacific, in the channels and in the inner fjords. The caridean shrimps were frequent only in the channels and the anomuran crabs in the fjords. Libidoclaea smithii and Munida subrugosa were the most frequent species in the fjords, whereas all other species were caught only occasionally opposite the glaciers. Close to the Pacific, L. smithii was the most frequent decapod of the 11 species registered within this area (cf. Table 1).
The decapods covered the whole depth range of sampling between 45 and $1218 \mathrm{~m}$ (Table 1). The brachyuran crabs were restricted to depths less than $200 \mathrm{~m}$, the caridean shrimps occurred between 75 and $438 \mathrm{~m}$, and the palinuran Stereomastis suhmi was found between 75 and $392 \mathrm{~m}$ depth. Only the Anomura covered the total depth range, but most specimens were taken at less than $450 \mathrm{~m}$ depth.

The material yielded a total of 248 individuals and most of them (219) were taken during the expedition in 1995. The most abundant species was Austropandalus grayi. However, the 141 specimens of this shrimp, making up almost $64 \%$ of all individuals caught during both years, were taken at a single station in 1995. Libidoclaea smithii (26 specimens), Eurypodius latreillii (16), Pagurus comptus (15), Munida subrugosa (14) and Campylonotus semistriatus (11) contributed another $24 \%$ to the material. All other species were rare, i.e. they occurred with less than 10 individuals in the total catch.

\section{DISCUSSION}

The material collected by RV "Vidal Gormaz" gave new insights into the distribution patterns of decapod crustaceans in the waters in front of the SPI. The 14 benthic species found in the channels and fjords next to the SPI represent a low number of decapod crustaceans in this particular area, when compared to the total of 46 species, which are known to be distributed between Chiloé Island and Cape Horn (Gorny, 1999). Species number of decapod crustaceans is also low in the higher latitudes of the Southern Ocean (Yaldwyn, 1965; Kirkwood, 1984; Gorny, 1999). However, in contrast to the Antarctic continental shelf, where caridean shrimps with few species are the only group of decapod crustaceans (Arntz and Gorny, 1991), four infraorders comprise the decapod fauna opposite the SPI.

Although no new species were found, our records extended the distribution range of Munida gregaria towards the north. M. gregaria was known to occur up to $52^{\circ} 55^{\prime}$ 'S (Retamal, 1973).

Brachyuran crabs are the most frequent infraorder opposite the SPI as in the whole southern part of South America, where the decapod fauna is dominated by brachyurans, with $62 \%$ of all known species (Gorny, 1999). Interestingly, although the brachyuran crab Libidoclaea smithii was the most frequent species in front of the SPI, the most abundant decapod was Austropandalus grayi, one of the 


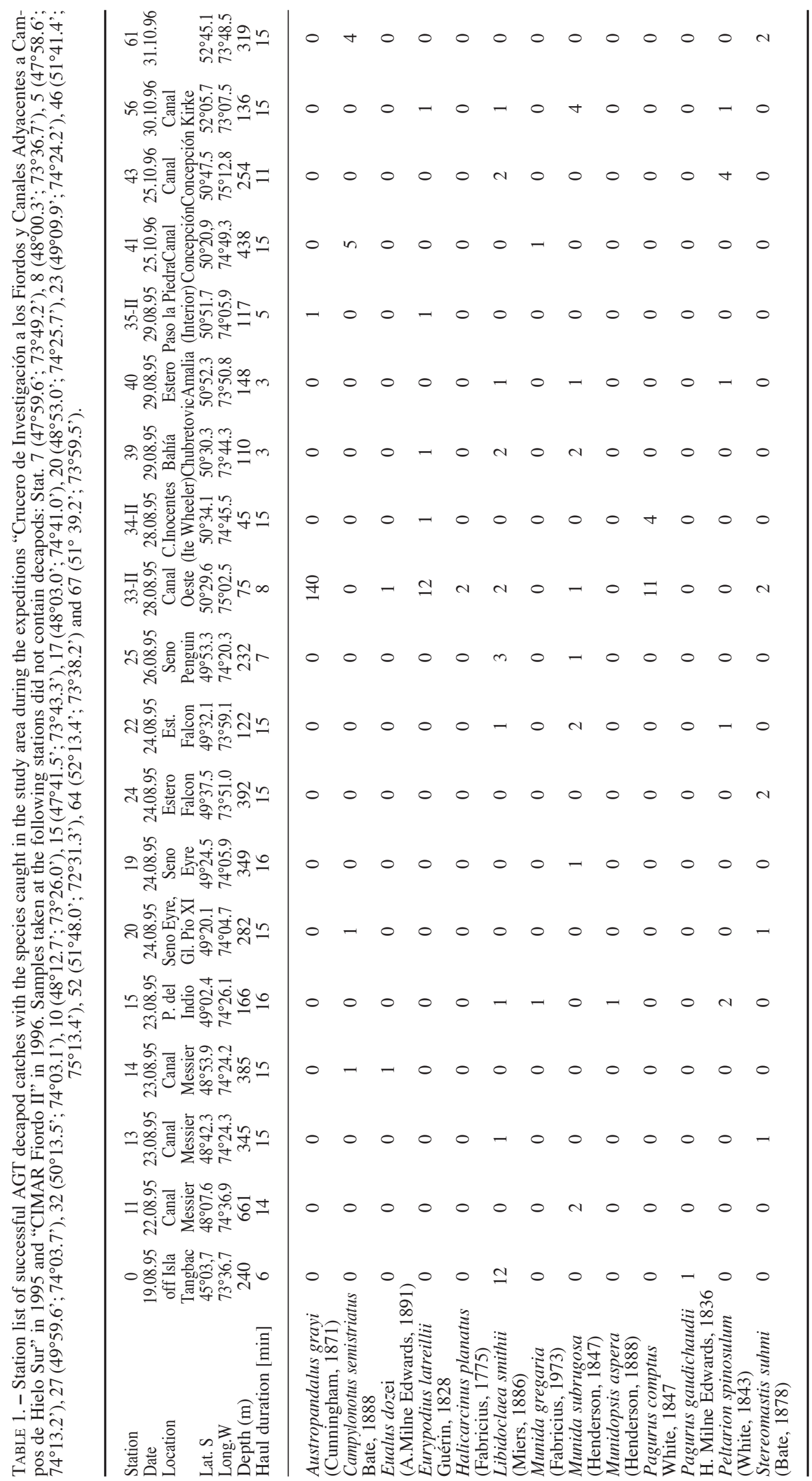


two pandalid species, which are distributed in the higher latitudes of the southern hemisphere (cf. Gorny, 1999). In the northern hemisphere another pandalid, Pandalus borealis is a key species of the fjord communities (Hopkins et al., 1989) along the Norwegian coast.

In conclusion, the decapod fauna seems to exhibit some special characteristics. The area opposite the SPI provides a natural and almost continuous transition from polar to temperate climate. In contrast to other areas in southern Chile, most parts of the sea floor opposite the SPI are covered with mud and clay. This type of habitat is preferred by only a few of those decapods which are distributed between Chiloé and Cape Horn. Among them are Libidoclaea smithii, Munida subrugosa and Campylonotus semistriatus, the three most frequent species we found, whereas others such as Eurypodius latreillii, Peltarion spinosulum and Halicarcinus planatus which live on sand, gravel or underneath the stones in the intertidal zone (Retamal, 1994; Gorny, 1999), were less frequent opposite the SPI. Furthermore Libidoclaea smithii and Munida subrugosa belong to the few species of the Southern Ocean decapod fauna with a high degree of eurybathy.

Presently species richness is higher at the oceanic sites. However, if the icefield moves further backwards, and shallow-water habitats increase, other species, now distributed at the Pacific sites, are likely to colonize the inner fjords also.

\section{ACKNOWLEDGEMENTS}

Thanks are due to the Comite Oceanográfico Nacional de Chile for financial support of the expedition. The International Bureau of the Ministery of Education and Research (Germany) and the International Foundation of Science (Sweden), Grant
$\mathrm{A} / 2503-1$, as well as the German Academic Exchange Service (DAAD) kindly contributed to partial financing of the work.

\section{REFERENCES}

Aniya, M and P. Skvarca. - 1992. Characteristics and variations of Uppsala and Moreno Glaciers, southern Patagonia. Jap. Soc. Snow Ice, 70-79.

Arntz, W.E. and M. Gorny. - 1991. Shrimp (Decapoda, Natantia) occurrence and distribution in the eastern Weddell Sea, Antarctica. Polar Biol., 11: 169-177.

Arntz, W.E., M. Gorny, R. Soto, M.A. Lardies, M. Retamal and I.S. Wehrtmann. - 1999. Species composition and distribution of decapod crustaceans in the waters off Patagonia and Tierra del Fuego, South America. Sci. Mar., 63(Supl. 1): 303-314.

Boschi, E.E., C.E. Fischbach and M.I. Iorio. - 1992. Catálogo ilustrado de los crustáceos estomatópodos y decápodos marinos de Argentina. Frente Marítimo, 10: 7-94.

Gorny, M. - 1999. On the biogeography and ecology of the Southern Ocean decapod fauna. Sci. Mar., 63(Supl. 1): 367-382.

Heusser, C.J. - 1984. Late Quaternary climates in Chile. In: J. C. Vogel (ed.), Late Caenozoic Palaeoclimates of the Southern Hemisphere, pp. 59-83. Balkema, Rotterdam.

Holthuis, L.B. - 1952. The Crustacea Decapoda Macrura of Chile. Reports of the Lund University Chile Expedition 1948-49. Lunds Univ. Arsskr, N. F. (2), 51 (12):1-68.

Hopkins, C.C.E., P.E. Grotnes and J.E. Eliassen. - 1989. Organization of a fjord community at $70^{\circ}$ North: the pelagic food web in Balsfjord, northern Norway. Rapp. P. -v. Réun. Cons. int. Explor. Mer, 188: 146-153.

Kirkwood, J.M. - 1984. A guide to the Decapoda of the Southern Ocean. ANARE Res. Notes, 11: 1-47.

Pinochet, P. and S. Salinas. - 1995. Estructura térmica y salina de canales y fiordos adyacentes a los campos de Hielo Sur. In: Comité Oceanográfico Nacional (eds), Crucero de Investigación Científica Marina a los Fiordos y Canales Adyacentes a campos de Hielo Sur. 18 de Agosto - 4 de Septiembre de 1995. Informe de Crucero, pp. 15-25. Litografía Carroza, Valparaíso.

Retamal, M.A. - 1973. Contribución al conocimiento de los crustáceos decápodos de la Región Magallánica. Gayana (Zool.), 29: 1-24.

Retamal, M.A. - 1974. Contribución al conocimiento de los crustáceos decápodos de la Región Magallánica II. Gayana (Zool.), 31: 3-23.

Ríos, C. and F.L. Guzmán. - 1982. Reevaluación de la estructura de la comunidad en una playa de bloques y cantos de alta latitud. Archipielago del Cabo de Hornos. Ans Inst. Pat., 13: 211-222.

Warren, Ch.R. and D.E. Sudgen. - 1993. The Patagonian icefield: a glaciological review. Arctic Alpine Res., 25 (4): 316- 331.

Yaldwyn, J.C. - 1965. Antarctic and subantarctic decapod Crustacea. In: J. Van Miegham and P. van Oye (eds), Biogeography and Ecology in the Antarctic, pp. 324-332. W. Junk Publ., The Hague. 